\title{
СУЧАСНІ АСПЕКТИ ВДОСКОНАЛЕННЯ РІВНЯ ФІЗИЧНОЇ ПІДГОТОВКИ МАЙБУТНІХ ПРАВООХОРОНЦІВ ЗАСОБАМИ СДИНОБОРСТВ
}

\begin{abstract}
Анотація. У статті розглядаються актуальні питання підвищення індивідуального рівня фізичної підготовленості майбутніх офіцерів Національної поліщії України із використанням різних засобів фрізичного виховання. На даний момент фізична культура в сучасному прояві набуває великої популярності серед представників різних верств населення. Засоби фізичного розвитку сприяють прискореному розвитку функціонального стану тих, хто тренуеться, атлетів, що безсумнівно е прийнятним для впровадження у систему фізичної підготовки правоохоронщів різних вікових груп та категорій. В статті визначено, що виконання завдань, покладених на працівників поліції, неможливе без засвоєння теоретичних знань із фізичної підготовки. Останні пропонуемо розуміти як результат оволодіння поліцейськими спеціальною системою знань, умінь, навичок із фізичної підготовки, необхідних для виконання повноважень поліцейського, а також для життедіяльності людини.
\end{abstract}

Ключові слова: єдиноборства, фрункціональна готовність, виховання, майбутні офіцери, фізична підготовка, функціональне багатоборство, заклади вищої освіти МВС України.

Anisimov Dmytro, Sheverun Vladyslav Dnipropetrovsk State University of Internal Affairs

\section{MODERN ASPECTS OF IMPROVING THE LEVEL OF PHYSICAL TRAINING OF FUTURE LAW ENFORCEMENT OFFICERS BY MEANS OF MARTIAL ARTS}

Summary. The article considers topical issues of increasing the individual level of physical fitness of future officers of the National Police of Ukraine with the use of various means of physical education. At the moment, physical culture in its modern form is becoming very popular among various segments of the population. Physical development tools contribute to the accelerated development of the functional state of trainees, athletes, which is undoubtedly acceptable for the introduction into the system of physical training of law enforcement officers of different ages and categories. This will increase the efficiency of the tasks assigned by law enforcement officers of the Ministry of Internal Affairs of Ukraine. The article stipulates that the performance of tasks assigned to police officers is impossible without the acquisition of theoretical knowledge of physical training. We propose to understand the latter as the result of mastering by police officers a special system of knowledge, skills, abilities in physical training, necessary for the performance of police duties, as well as for human life. Hand-to-hand combat, as one of the sports, requires duration and proper training, its effectiveness is manifested through a thorough understanding of the basic aspects of training and the ability to use different training tools for the formation and development of basic physical qualities. The paper proves that the basic knowledge required for the effective development of physical qualities of police officers includes the following: knowledge of methods, forms, means of developing basic physical abilities; knowledge of regulations governing the organization of physical training in the units of the National Police of Ukraine. In the article it was formulated that physical education of cadets in the mode of educational work is carried out in the following forms. First, the training sessions provided by the curriculum and schedule of the university. There are theoretical and practical classes. Theoretical - lectures, methodical workshops, consultations, interviews. Practical - workshops, consultations, credit competitions, control tests, competitions in general physical training and the chosen sport.

Keywords: functional readiness, education, future officers, physical training, functional all-around, higher education institutions of the Ministry of Internal Affairs of Ukraine.

$\Pi^{2}$ остановка проблеми. Аналіз статистичних даних аналітиків МВС України показуе зростання злочинності у 2017-2021 роках. Вказане вище свідчить про необхідність пошуку шляхів вирішення проблем, пов'язаних з навчанням співробітників правоохоронних органів ефективного виконання поставлених перед ними завдань.

Фізична культура, володіючи величезним потенціалом не тільки в плані покращення фрізичної форми, здоров'я, але і як засіб формування особистості курсанта, як жодна інша діяльність, може бути спрямована на вирішення низки психофрізичних, сопіально-психологічних та естетичних проблем.

Вона представлена у закладах вищої освіти (далі - ЗВО) як важлива складова формування цілісного розвитку особистості курсанта. Як невід'ємна частина загальної культури, вона є частиною гуманітарної складової освіти, важливість якої проявляеться у гармонізації духовних, моральних та фізичних сил.

Глибоке розуміння фізичної культури особистості курсанта як соціальної та індивідуальної цінності може стати реальністю для розвитку різноманітних видів фізичної культури у ЗВО України. Вона може сприяти формуванню прогресивних напрямів у розвитку суспільної думки, особистих мотивів та потреб у розвитку цінностей фрізичної культури.

Освоення цінностей фізичної культури дає молоді розуміння складнощів життя, допомагае виробити духовні та етичні критерії самооцінки. Це, своєю чергою, вимагає формування та розвитку здібностей до загальнокультурного самовираження, що у практиці означае формування потреби у культурної інформації та знаннях, вміння 
розпізнавати справжні культурні цінності. Проявом џього прагнення є участь курсантської молоді у створенні та фрункціонуванні ініціативних об'єднань у сфрері спортивної діяльності, здатність проводити змістовно та творчо вільний час, використовуючи різноманітність можливостей, що надаються різними видами фізичної культури.

В. Аред'єв наголошуе, що поняття «фрізична культура» - це частина загальної культури, сукупність особливих матеріальних та духовних цінностей, способів їх створення та використання для забезпечення фізичного вдосконалення людини.

За словами Свсеєва, «фізична культура - це частина (підсистема) загальної культури людства, яка є творчою діяльністю зі засвоєння минулого та створення нових цінностей, головним чином у галузі розвитку, реабілітації та освіти».

Аналіз останніх досліджень та публікацій. Питанням удосконалення рівня фрізичної підготовленості курсантів системи МВС України присвячені роботи учених: Баштової А.Г., Гаркавого О.А., Закорка І.П., Коломійця Ю.М., Селюкова В.С., Трішина К.О., Уварової О.Ю., Хацаюка O.B., Чуха A.M. та інш. Цікавими за своїм змістом є роботи: Демківа А., Кузнецова М., Єни М., Пилипчака I., Базилевича Н. та інших фахівців даного напряму, у яких розкриваються методичні складові впровадження засобів кросдріт в освітній процес військовослужбовців та курсантів вищих військових навчальних закладів МО України та інших силових структур.

Виділення невирішених раніше частин загальної проблеми. У категоріальне поле поняття «фізична культура особистості курсанта» входять поняття: "культура", «фізична культура", «фізична культура особистості» та «фізичне виховання». Насамперед зазначимо, що це поняття немає однозначного трактування в психолого-педагогічних теоріях і змінюються залежно від рівня розвитку суспільства, науки загалом і педагогіки зокрема.

За визначенням різних авторів, поняття фрізичної культури особистості відбиває три напрями: 1) фрізична культура як сукупність усіх досягнень суспільства, матеріальних та духовних цінностей, створених людством протягом його історії; 2) історично зумовлений рівень розвитку суспільства та людини, що сприяе впливу на фрізичний розвиток та фізичне виховання та шляхи фізичного вдосконалення людей; 3) частина загальної культури, сукупність особливих духовних та матеріальних цінностей, способи ї виробництва та використання з метою оздоровлення людей та розвитку їх фрізичних здібностей.

Питання дослідження окремих джерел, вивчення їх особливостей $з$ метою розробки загальних та специфічних методів, інструментів, важелів, що сприяють розвитку фрізичної культури засобами єдиноборств є недостатньо вивченими.

Постановка завдання. Обгрунтування необхідності впровадження засобів функціонального розвитку фрізичної культури в освітній процес майбутніх офріцерів НПУ.

Виклад основного матеріалу дослідження. Зміст фізичної культури та пов'язаних 3 нею явищ можна розділити на дві основні частини:

- фрункціональність та безпека, які представлені всім тим цінностям, які створюються та використовуються суспільством як спещіальні інструменти, методи та умови, що дозволяють оптимізувати фрізичний розвиток та забезпечувати певний рівень фрізичної підготовленості;

- едективні, представлені позитивними результатами фрізичного розвитку та тренувань внаслідок застосування засобів, методів та умов.

Ці частини культури - єдине ціле. Перше поступово зливається 3 другим через практичну діяльність у контексті фрізичного виховання, фрізкультурно-оздоровчої діяльності, масового фрізкультурно-спортивного руху. Однак між частинами фрізичної культури на певних етапах їі розвитку можуть бути незначні і навіть суттеві відмінності через неузгодженість окремих елементів змісту. Наприклад, за високого рівня матеріальної підтримки та низької кваліфікації робітників неможливо досягти належного рівня фрізичної підготовки.

Таким чином, у нашому розумінні фрізична культура $є$ частиною культури суспільства, яка спрямована на створення здорового способу життя, фрізичне вдосконалення, задоволення своїх моральних, естетичних та творчих потреб, а також на духовний розвиток особистості.

Фізична підготовка працівників правоохоронних органів України - це освітній процес, спрямований на формування певних фрізичних здібностей до професійної діяльності 3 певними професійними характеристиками. Фізична підготовка у правоохоронних органах має забезпечувати підтримку здоров'я, творчу та трудову активність, всебічний розвиток фрізичних характеристик, професійних навичок та умінь співробітників, необхідних для виконання оперативних завдань [1, с. 65].

Фізичне виховання спрямоване рішення таких освітніх завдань: забезпечити раціональне формування індивідуального фонду необхідних рухових знань, навичок і умінь з метою доведення їх до рівня досконалості; навчити всіх застосовувати отримані знання та навички у повсякденному житті для самовдосконалення.

Силова підготовка включає підвищення максимальних показників силових якостей, а також підвищення працездатності пропорційно до рівня розвитку силових якостей, спортивного інвентарю та роботи автономних систем. Коли всі аспекти функціональних можливостей спортсмена об'єднані у єдину узгоджену систему, функціональні можливості повністю впливають рівень результативності у різних видах спорту.

Силові тренування - це різні вправи, які впливають або всю мускулатуру, або окремі групи м'язів. Вправи для збільшення загальної сили тренування можна виконувати за допомогою допоміжних засобів або без них. Найбільш едективними є вправи зі штангою, м'ячами 3 наповнювачем, гантелями, гумовими бамперами, еспандерами, блочними тренажерами та ізокінетичними тренажерами.

Рукопашний бій, як один із видів спорту, вимагає тривалого та правильного тренування, його едективність проявляеться за рахунок досконалого розуміння основних аспектів тренувального процесу та можливості використання різних тренувальних засобів для формування та розвитку основних фрізичних якостей. 
Застосування прийомів рукопашного бою, що $\epsilon$ синтезом захисних рухів руками і ногами із захопленням, больовоми прийомами, задушенням і технікою кидка, що пред'являе досить високі вимоги до пристосованості спортсмена до ациклічних проявів динамічних і статичних зусиль.

На думку ряду дослідників Чорнозуб А.А., Адамович Р.Г., Штефюк І.К. та ін., спеціальна підготовка спортсменів у рукопашному бою повинна бути спрямована на розвиток та вдосконалення швидкості, спритності, сили, особливої витривалості та гнучкості.

Тому для розвитку швидкісних та силових якостей дослідники рекомендують наступні вправи: кидання набитого м'яча однією та двома руками з різних положень; у положенні лежачи на спині згинання та розгинання рук (з ударами в груди, по голові, за спиною); присідання та стрибки із положення лежачи; різні вправи у волані; стрибки на одній і двох ногах у присіді.

Ще одна важлива та ефективна практика силових тренувань у рукопашному бою - кросфріт система різних силових вправ високої сили, за допомогою яких можна досягти максимального ефекту від тренувань та позитивно сприяти розвитку функціональних систем організму.

За наслідками дослідження Корчагін М.В., Мартиненко O.М. та Хомонюк С.В. дійшли висновку, що з використанні комплексів системи кросфріт у програмі базової підготовки у рукопашному бою спостерігаеться статистично значуще збільшення абсолютної сили і покращуеться витривалість.

Відповідно до вимог програм навчання та роботи зі спеціальної фрізичної підготовки у ЗВО МВС України, працівники поліції мають освоювати навчальний матеріал не лише на практиці, а й за самостійного та індивідуального навчання. Метою цих курсів $\epsilon$ поглиблення теоретичних знань та вдосконалення методичної підготовки з фізичної культури. Вони забезпечують самостійне вивчення документів та навчальних посібників з фiзичної культури та спорту, уточнюють завдання та зміст практичних занять, виконують вправи та досліджують методи їх організації.

Без набуття теоретичних знань з фрізичної підготовки неможливо ефективно виконувати завдання, поставлені перед співробітниками поліції. Під останнім ми пропонуемо розуміти результат оволодіння поліцією особливої системи знань, навичок і умінь у сфрері фрізичної підготовки, необхідні для виконання поліцейських завдань, і навіть для повсякденного життя людини [2, с. 85].

Методичні знання з фізичного виховання це система даних про концептуальну основу методів навчання в галузі фрізичного виховання, здатність людини застосовувати їх у навчальному процесі та передачу компетенцій учасникам у цьому процесі. Теоретичні та методологічні знання виявляються в умінні розробляти, адаптувати, організовувати, мотивувати, досліджувати та контролювати процес фізичного виховання. Загалом аналізовані знання 3 фізичного виховання співробітників поліції можна поділити на базові та додаткові знання, необхідні як під час фізичного виховання, так і для виконання службових завдань.
Основні навички, необхідні для ефективного розвитку фізичних якостей співробітників поліції включають: знання методів, форм та засобів розвитку основних фрізичних навичок; знання положень щодо організації фрізичної підготовки у підрозділах Національної поліції України.

Додаткові теоретичні знання - основа правил особистої гігієни, контролю та самоконтролю під час навчання.

За рахунок комплексного використання базових і додаткових теоретичних та методологічних знань з фізичного виховання можна досягти максимальної ефективності у навчанні майбутніх співробітників поліції та у навчанні співробітників правоохоронних органів.

Засвоення цих знань дозволяе правильно оцінювати ситуащію, окремі ситуації, вибирати оптимальні дії, прийоми та комбінації прийомів. Тому невипадково, що навчальні програми для поліцейських включають як практичні заняття з конкретної фізичної підготовки, так і певну кількість годин на засвоєння теоретичного матеріалу [3, с. 15].

Слід зазначити, що збільшення навчального навантаження 3 дисципліни «Спеціальна фізична підготовка" хоч і призводить до підвищення практичних навичок курсантів, які стануть у нагоді їм у майбутній професійній діяльності, але це не $е$ зовсім раціональним. Сьогодні до навчальної програми МВС України включено лише дисципліну "Спеціальна фізична підготовка", зміст якої відповідає професійній спрямованості курсантів. Однак немає таких предметів як «Фізична культура» або «Фізичне виховання». Основні засади фізичного виховання викладаються у загальній частині «спеціального фрізичного виховання», що і має професійну спрямованість.

Тому, на наш погляд, програми підготовки курсантів 3ВО МВС України мають бути доповнені обов'язковою дисципліною «Загальна фрізична підготовка». Це дозволить не лише краще підготувати майбутніх співробітників поліщії до практичної діяльності, а й диференщіювати кількість та вид завантаженості курсантів з урахуванням спеціальності та специфіки їхньої майбутньої діяльності. Наприклад, для «Загальної фізичної підготовки» має бути передбачена однакова кількість академічних занять з усіх предметів та за всіма напрямками, а навантаження для «СФП» має відповідати спеціальному напрямку підготовки. Наприклад, навантаження на курсантів підрозділів кримінальної поліції мае бути вищим, ніж на курсантів, які в майбутньому стануть слідчими [4, с. 65$]$.

Також слід звернути увагу щодо посилення практичної підготовки за спеціальністю, тобто, спеціальна фізична підготовка має проводитися з урахуванням сучасних тенденщій у «розвитку» злочинності. Підготовка поліцейських у контексті фрізичного виховання має відповідати завданням, з якими поліцейські стикаються безпосередньо під час своєї практичної роботи.

Слід підтримати думку O.М. Зілмана, який звертає увагу на важливість поєднання теоретичної та практичної підготовки у навчанні та розвитку професійної та психологічної готовності курсантів до правоохоронної діяльності.

На нинішньому етапі реформи відомчої освіти недоцільно обмежувати викладання певних 
дисциплін у юридичній, тактико-спеціалізованій, протипожежній, фрізичній та іншій освіті. Необхідно проводити комплексну підготовку курсантів і водночас раціонально використовувати міждисциплінарні зв'язки та об'єднувати їх у конкретних навчальних курсах, щоб створити у співробітників поліції найвищу якість профресійної готовності до відповідних завдань.

Моделювання життевих ситуацій, які можуть виникнути при розгортанні та службовій діяльності співробітників поліції на курсах «Спеціальної фрізичної підготовки» через міждисциплінарні зв'язки, дозволить більш практично навчати курсантів.

На цьому етапі розвитку системи освіти МВС України перед відомчими ЗВО стоїть завдання підготовки та навчання фрахівців, здатних до розумової та фізичної роботи. Вирішення цих проблем йде пліч-о-пліч з необхідністю підтримувати і зміцнювати здоров'я курсантів, покращувати фрізичну працездатність, долати гіпокінезію і дотримуватися основ здорового способу життя за допомогою занять фрізкультурою.

Наукові підходи до досліджень щодо вдосконалення фрізичного виховання в основному спрямовані на розвиток фізичних якостей курсантів, покращення фрункціонування організму, підготовку до майбутньої професійної діяльності та покращення фрізичної підготовленості.

Більшість курсантів, які навчаються у 3 ВО $\mathrm{MBC}$, не займаються фрізичним самовдосконаленням. Для вирішення цієї проблеми необхідно шукати едрективні підходи до організації форм фрізичного виховання. Слід зазначити, що найважливіше місце у науковій організації курсантської роботи займає фрізичне виховання, функції якого у вищій школі складні та суттево впливають на навчальну, пізнавальну, профресійну та соціальну діяльність курсантів.

Фізична культура впливає на процес фрормування духовної культури, естетичного смаку, моральних норм, покращуе настрій, загальний і психоемоційний стан організму, збільшуе пам'ять і увагу [6, с. 15].

У світлі сучасних уявлень про здоров'я людини зростає значення раціонально організованого фрізичного виховання у ЗВО, яке стає найважливішим фактором забезпечення високого фрункщіонального стану організму та оптимальної розумової працездатності курсантів. Процес навчання вимагає напруження пам'яті, стійкості та концентрації, часто супроводжується стресовими ситуаціями, що підкреслюють багато вчених.

Процес фрізичного виховання - це комплекс засобів фізичної культур та спеціальних засобів впливу, спрямованих на фрізичний та профресійний розвиток майбутнього працівника та формування потреби у фізичному самовдосконаленні.

Використання засобів розвитку мотиваційної сдери курсантів фрізичного виховання сприяе формуванню стійкого інтересу до фрізичного виховання та, як наслідок, усвідомленого ставлення до самовдосконалення.

До основних заходів щодо формування фізичного виховання можна віднести наступне:

- організація процесу фрізичного виховання 3 урахуванням інтересів курсантів, використання різних видів фрізичної активності;
- створення умов для застосування до курсантів самостійної фрізичної підготовки;

- оздоровчо-профілактичний характер навчання у поєднанні з фракторами здорового способу життя;

- систематичне теоретичне навчання, яке відразу відпрацьовуеться на практиці;

- забезпечення диференційованого підходу на заняттях за результатами моніторингу фізичного стану курсантів [7, с. 110].

Слід зазначити, що фрізичне виховання у ЗВО здійснюеться протягом усього періоду навчання у рамках навчальної діяльності та у позанавчальний період.

Фізичне виховання курсантів за видом виховної роботи здійснюеться у таких фрормах. По-перше, навчання передбачено навчальним планом та графіком вузу. Є теоретичні та практичні курси. Теоретична - лекції, методичні заняття, консультації, співбесіди. Практичні майстер-класи, консультації, залікові змагання, контрольні випробування, змагання 3 загально-фізичної підготовки та обраного виду спорту [8].

По-друге, фракультативні курси, які є продовженням та доповненням до основних фрорм навчання. На фракультативних заняттях удосконалюеться фрізична підготовка курсантів відповідно до вимог норм програми, поглиблюеться професійна фізична підготовка, розширюються знання теорії та методики фізичного виховання, продовжуеться підготовка до майбутньої громадської та профресійної діяльності.

Протягом навчального року у вихідні дні та під час канікул проводяться масові фрізкультурні та спортивні заходи. До них відносяться походи, спортивні свята, дні здоров'я, спортивні ігри, змагання 3 міжвузівським календарем та заходи в університеті.

Крім вирішення педагогічних та соціальних завдань, фізичне виховання спрямоване на підвищення фрізичної активності курсантів ЗВО MBC: підвищення профресійної та прикладної підготовленості та оптимізація успішності за рахунок зниження нервової та емоційної напруги; продовження формування знань, умінь та навичок у зв'язку із здійсненням саморозвитку в сфеpi фрізичної культури [9, с. 76].

Варто зазначити, що в деяких курсантів банально відсутня мотивація на зайняття спортом. Відсутність мотивації є причиною відсутності оздоровчої орієнтації та ведення здорового способу життя. Формування мотивації до занять фізичною культурою потребуе впровадження різних сучасних фрорм занять з урахуванням індивідуальних можливостей курсантів.

Едективність фрізичного виховання курсантів у вигляді стійкої зацікавленості, що сорормувалася, в самостійному фізичному вдосконаленні може бути досягнута за рахунок цілеспрямованого форомування ціннісного ставлення до фрізичної культури і спортивної діяльності на всіх етапах підготовки майбутнього правоохоронця. Оптимізація процесу спортивно-масової роботи з курсантами ЗВО МВС має бути регламентована 3 врахуванням специфіки профресійної діяльності випускників ЗВО зі специфічними умовами навчання. 
Висновки з даного дослідження. Таким чином, враховуючи все вищесказане, ми дійшли таких висновків:

- актуальність фозичного виховання для молоді в Україні не потребуе подальших аргументів, наявна гостра потреба у систематичному підвищенні рівня фрізичних навичок майбутніх правоохоронців;

- важливість та необхідність якісної фрізичної підготовки поліщейських за допомогою бойових мистецтв зумовлені не лише специфрікою їхньої службової діяльності, а й загальними вимогами для розвитку здорової молоді, тому дана підготовка спрямована не лише на розвиток професійно-активної особистості, а й на розумної та впевненої в собі людини;

- серед проблемних питань, що виникають у галузі фрізичної підготовки курсантів за допомогою единоборств, слід виділити неправильну диференціацію навчального матеріалу для курсантів 3 різних напрямів підготовки, проблема не регулярної підготовки, що призводить до зниження навантаження та нівелювання мети фpiзичного виховання.

\section{Список літератури:}

1. Дідковський В. А., Бондаренко В. В., Кузенков О. В. Фізична підготовка працівників Національної поліції України : навч. посіб. Київ : Нац. акад. внутр. справ ; ФОП Кандиба Т. П., 2019. 98 с.

2. Ольховий О. М. Теоретико-методичні основи професійно-спрямованої фізичної підготовки курсантів ВВНЗЗС України : монографія. Харків : ХУПС, 2012. 286 с.

3. Петрачков О. В. Професійно-прикладна підготовка курсантів у навчальному центрі сухопутних військ із застосуванням удосконалених нормативів фрізичної підготовленості : автореф. дис. ... канд. пед. наук : 13.00.04. Хмельницький, 2012. 20 с.

4. Хацаюк О. В., Любчич Р. І., Оленченко В. В. Удосконалення військовопродесійних навичок військовослужбовців Національної гвардії України в процесі спеціальної фрізичної підготовки. Проблели вищої освіти. 2019. № 1(95). C. 63-69.

5. Анудріев М. І., Бутов С. С., Гіда О. Ф., Решко С. М. Основи спеціальної фізичної підготовки працівників МВС. Київ : Нац. акад. МВС України, 2003. 338 с.

6. Бабенко В. Г., Попов О. В., Янко І. В. Заходи фрізичного впливу : метод. рек. Київ, 2001. 24 с.

7. Луцака Д. О. Юридична психологія та педагогіка. Науковий журнал. 2011. № 1(9). С. $107-115$.

8. Кафедра бойової та спеціальної фізичної підготовки. Донецький юридичний інститут МВС Украӥни : сайт. URL: https://www.dli.donetsk.ua/structure/departs/dep-bsp (дата звернення: 15.04.2021).

9. Головацький О. О. Службова підготовка поліцейських в умовах реформування системи МВС України: теоретико-правовий аспект. Підготовка поліцейських в уловах рефбормування систели МВС Украӥни : зб. наук. пр. за матеріалами II Міжнар. наук.-практ. конф. (м. Харків, 21 квітня 2017 р.) / МВС України, Харків. нац. ун-т внутр. справ. Харків, 2017. С. 75-78. URL: http://univd.edu.ua/general/publishing/konf/ 21_04_2017_1/pdf/12.pdf (дата звернення: 09.04.2021).

10. Стріха С. В. Організація та методика самостійного тренування. Проблели та перспективи спеціальної підготовки правоохоронних органів Украйни : зб. матеріалів круглого столу від 25 травня 2017 року. Київ : IKBC, 2017. C. 28-32.

\section{References}

1. Didkovskyi V. A., Bondarenko V. V., Kuzenkov O. V. (2019) Fizychna pidhotovka pratsivnykiv Natsionalnoi politsii Ukrainy [Physical training of employees of the National Police of Ukraine]: navch. posib. Kyiv: Nats. akad. vnutr. sprav; FOP Kandyba T. P., 98 p. (in Ukrainian)

2. Olkhovyi O. M. (2012) Teoretyko-metodychni osnovy profesiino-spriamovanoi fizychnoi pidhotovky kursantiv VVNZZS Ukrainy [Theoretical and methodical bases of professionally-directed physical training of cadets of VVNZZS of Ukraine]: monohrafiia. Kharkiv: KhUPS, 286 p. (in Ukrainian)

3. Petrachkov O. V. (2012) Profesiino-prykladna pidhotovka kursantiv u navchalnomu tsentri sukhoputnykh viisk iz zastosuvanniam udoskonalenykh normatyviv fizychnoi pidhotovlenosti [Professional and applied training of cadets in the training center of the ground forces with the use of advanced standards of physical fitness]: avtoref. dys. ... kand. ped. nauk: 13.00.04. Khmelnytskyi, 20 p. (in Ukrainian)

4. Khatsaiuk O. V., Liubchych R. I., Olenchenko V. V. (2019) Udoskonalennia viiskovoprofesiinykh navychok viiskovosluzhbovtsiv Natsionalnoi hvardii Ukrainy v protsesi spetsialnoi fizychnoi pidhotovky [Improving the professional skills of servicemen of the National Guard of Ukraine in the process of special physical training]. Problemy vyshchoi osvity, no. 1(95), pp. 63-69. (in Ukrainian)

5. Anufriiev M. I., Butov S. Ye., Hida O. F., Reshko S. M. (2003) Osnovy spetsialnoi fizychnoi pidhotovky pratsivnykiv MVS [Basics of special physical training of employees of the Ministry of Internal Affairs]. Kyiv: Nats. akad. MVS Ukrainy, 338 p. (in Ukrainian)

6. Babenko V. H., Popov O. V., Yanko I. V. (2001) Zakhody fizychnoho vplyvu [Physical exposure measures]: metod. rek. Kyiv, 24 p. (in Ukrainian)

7. Lutsaka D. O. (2011) Yurydychna psykholohiia ta pedahohika [Legal psychology and pedagogy]. Naukovyi zhurnal, no. 1(9), pp. 107-115. (in Ukrainian)

8. Kafedra boiovoi ta spetsialnoi fizychnoi pidhotovky. Donetskyi yurydychnyi instytut MVS Ukrainy [Department of Combat and Special Physical Training]: sait. Available at: https://www.dli.donetsk.ua/structure/departs/dep-bsp (accessed 25 September 2021). (in Ukrainian)

9. Holovatskyi O. O. (2017) Sluzhbova pidhotovka politseiskykh v umovakh reformuvannia systemy MVS Ukrainy: teoretyko-pravovyi aspekt [Service training of police officers in the conditions of reforming the system of the Ministry of Internal Affairs of Ukraine: theoretical and legal aspect]. Pidhotovka politseiskykh $\mathrm{v}$ umovakh reformuvannia systemy MVS Ukrainy: zb. nauk. pr. za materialamy II Mizhnar. nauk.-prakt. konf. (m. Kharkiv, 21 kvitnya 2017 r.) / MVS Ukrainy, Kharkiv. nats. un-t vnutr. sprav. Kharkiv, pp. 75-78. Available at: http://univd.edu.ua/general/publishing/konf/21_04_2017_1/pdf/12.pdf (accessed 25 September 2021). (in Ukrainian)

10. Strikha S. V. (2017) Orhanizatsiia ta metodyka samostiinoho trenuvannia. Problemy ta perspektyvy spetsialnoi pidhotovky pravookhoronnykh orhaniv Ukrainy [Organization and methods of self-training]: zb. materialiv kruhloho stolu vid 25 travnia 2017 roku. Kyiv: IKVS, pp. 28-32. (in Ukrainian) 